\title{
Antisipasi Bahaya Psikososial Stress Terhadap Kelelahan Kerja Pada Perawat
}

\author{
Natasia Atania Sitepu \\ natasiaatania2@gmail.com
}

\section{Latar Belatakang}

Perawat memegang peranan yang sangat strategis, karena kebanyakan tenaga kesehatan adalah perawat. Perawat adalah sumber daya terpenting dalam memberikan pelayanan dirumah sakit yang hampir disetiap negara $80 \%$ pelayanan kesehatan diberikan oleh perawat. Perawat sebagai pemberi jasa keperawatan merupakan ujung tombak pelayanan di rumah sakit, sebab perawat berada dalam 24 jam memberikan asuhan keperawatan. Perawat dalam fungsinya sebagai tenaga kesehatan selalu ditempatkan pada semua bagian rumah sakit, baik dalam sisi fungsional maupun structural. Dengan demikian kualitas pelayanan kesehatan ditentukan oleh mutu pelayanan keperawatan dengan peran perawat.

Potensi bahaya di rumah sakit, selain penyakit-penyakit infeksi juga ada potensi bahayabahaya lain yang mempengaruhi situasi dan kondisi di rumah sakit, yaitu kecelakaan (peledakan, kebakaran, kecelakaan yang berhubungan dengan instalasi listrik, dan sumber-sumber cedera lainnya), radiasi, bahan-bahan kimia yang berbahaya, gas-gas anestesi, gangguan psiko-sosial, dan ergonomi. Semua potensi-potensi bahaya tersebut jelas mengancam jiwa bagi kehidupan bagi para karyawan di rumah sakit, para pasien maupun para pengunjung yang ada di lingkungan rumah sakit.

Dari berbagai potensi bahaya tersebut, maka perlu upaya untuk mengendalikan, meminimalisasi dan bila mungkin meniadakannya, oleh karena itu K3 rumah sakit perlu dikelola dengan baik. Pengendalian terhadap bahaya kecelakaan kerja ini sangat penting untuk dilakukan demi keselamatan kerja para karyawan. Karena pada hakekatnya Keselamatan dan Kesehatan Kerja (K3) merupakan suatu usaha untuk menciptakan perlindungan dan keamanan dari berbagai risiko kecelakaan dan bahaya, baik fisik, mental maupun emosional terhadap pekerja, perusahaan, 
masyarakat dan lingkungan agar selalu dalam keadaan selamat dan sehat, serta agar setiap produksi digunakan secara aman dan efisien.

Pekerjaan seorang perawat merupakan pekerjaan yang memiliki stres yang tinggi, karena dalam bekerja, perawat berhubungan langsung dengan berbagai macam pasien dengan diagnosa penyakit dalam respon yang berbeda-beda. Tingginya stres yang dialami perawat dalam bekerja menjadikan perawat jenuh dan bosan, akhirnya berpengaruh terhadap produktivitas kerja dan penurunan kinerja perawat dan juga caring dari perawat itu sendiri.

Kelelahan kerja merupakan bagian dari permasalahan umum yang kompleks yang tidak hanya menyangkut kelelahan fisiologis dan psikologis dan sering dijumpai pada tenaga kerja dan secara nyata dapat mempengaruhi kesehatan tenaga kerja, penurunan kinerja fisik, adanya perasaan lelah, penurunan motivasi dan penurunan produktivitas kerja.

Menurut Rees 1982 dan Silalahi 1990 dalam Pongantung et al, 2018 menjelaskan bahwa stres dapat mempengaruhi kelelahan kerja namun berbeda bagi setiap pekerja.

Salah satu bahaya yang ada ditempat kerja adalah bahaya psikososial. Bahaya psikososial dapat menyebabkan stres pada pekerja, hal ini dapat disebabkan oleh akumulasi stressor pada situasi kerja di tempat kerja. Stres merupakan salah satu bahaya psikososial yang berpotensi menyerang semua jenis pekerjaan. Dengan demikian stres kerja merupakan masalah yang terjadi diseluruh dunia sehingga tidak bisa diabaikan begitu saja.

Stres kerja yang berkepanjangan selain menimbulkan gangguan kesehatan dapat pula menurunkan produktivitas. Dengan melihat besarnya potensi stres kerja terhadap kelelahan pada perawat oleh karena itu penulis mengangkat judul "Antisipasi Bahaya Psikososial Stress Terhadap Kelelahan Kerja Pada Perawat”

\section{Metode}

Metode yang digunakan dalam penulisan ini adalah metode kualitatif yang dimana penulis mengumpulkan data sebanyak-banyaknya untuk dianalisis. Tulisan ini didasarkan dengan menganalisis berbagai jurnal atau karya tulis ilmiah yang berfokus pada "Antisipasi Bahaya Psikososial Stress Terhadap Kelelahan Kerja Pada Perawat”. Adapun tinjauan literatur yang 
digunakan dalam penulisan ini menggunakan metode kajian bebas terhadap pokok bahasan yang dikumpulkan dari jurnal atau karya tulis ilmiah yang bersal dari E-book atau Google Scholar dengan syarat literatur yang digunakan terbitan 10 tahun terakhir. Pengolahan ini dilakukan dengan metode membandingkan beberapa jurnal atau karya tulis ilmiah yang digunakan dan berhubungan dengan bahaya psikososial stress terhadap kelelahan kerja pada perawat.

\section{Hasil}

Setiap perawat berharap agar selalu bisa melakukan sesuatu untuk menyelamatkan pasien yang dirawatnya. Hal tersebut menjadikan stresor tersendiri bagi perawat yang bertugas. Tingginya stres yang dialami perawat dalam bekerja menjadikan perawat jenuh dan bosan, akhirnya berpengaruh terhadap produktivitas kerja dan penurunan kinerja perawat dan juga caring dari perawat itu sendiri.

Stres kerja dapat berhubungan dengan kecelakaan dan kekerasan di tempat kerja. Kelelahan kerja merupakan kriteria yang lengkap tidak hanya menyangkut kelelahan yang bersifat fisik dan psikis saja tetapi lebih banyak kaitannya dengan adanya penurunan kinerja fisik, adanya perasaan lelah, penurunan motivasi, dan penurunan produktivitas kerja. Faktor-faktor yang dapat berpengaruh terhadap terjadinya kelelahan kerja, bermacam-macam, mulai dari faktor lingkungan kerja yang tidak memadai untuk bekerja sampai kepada masalah psikososial dapat berpengaruh terhadap terjadinya kelelahan kerja.

Dampak dari stress kerja terhadap kelelahan kerja dapat menimbulkan penurunan efisiensi kerja, penurunan keterampilan, peningkatan kecemasan atau kebosanan, dapat pula berpengaruh pada efektivitas dan produktivitas serta keselamatan tenaga kerja pada umumnya. Tingkat kelelahan yang tinggi dapat menyebabkan kecelakaan kerja yang disebabkan oleh human error.

Perawat yang mengalami kelelahan emosional tidak akan merasakan kepuasan kerja dan tidak dapat menunjukkan kinerja yang diharapkan. Perawat dirumah sakit mengalami kelelahan kerja hal tersebut dilihat dari keluhan yang dirasakan perawat seperti mudah marah, sulit konsentrasi serta perasaan lelah. Perawat bekerja lembur lelah, yang mungkin membuat mereka lebih rentan melakukan kesalahan. Mungkin juga lembur wajib terkait dengan kekurangan staf. 
Upaya pengendalian bahaya psikososial adalah menghindari rasa takut pada pekerjaan yang membuat psikologi terganggu pada saat bekerja sehingga tidak ada penyakit akibat kerja dan kecelakaan kerja. Melakukan manajemen kerja dengan melakukan pelatihan sehingga dapat mengetahui cara penanganan yang baik dan benar.

\section{Pembahasan}

Bahaya adalah segala seuatu yang dapat menyebabkan seseorang mengalami cidera sedangkan psikososial adalah istilah yang digunakan untuk menggambarkan hubungan antara kondisi sosial seseorang dengan mental/emosinya sehingga bahaya psikososial dapat didefenisikan hubungan antara kondisi sosial (bahaya sosial) seseorang dengan mental/emosinya di tempat kerja.

Bahaya psikososial didefinisikan oleh International Labour Organization mengacu pada interaksi antara dan di antara lingkungan kerja, isi pekerjaan, kondisi organisasi dan kapasitas pekerja, kebutuhan, budaya, pertimbangan ekstra-pekerjaan pribadi yang dapat, melalui persepsi dan pengalaman, mempengaruhi kesehatan, kinerja kerja dan kepuasan kerja.

Bahaya psikososial untuk perawat termasuk kekhawatiran tentang pajanan pekerjaan yang berbahaya, kekhawatiran tentang kekerasan yang ditujukan kepada mereka, beban kerja yang berat, tingkat tanggung jawab yang tinggi, ketidaksopanan / rasa tidak hormat dan intimidasi oleh rekan kerja dan supervisor / manajer, staf yang buruk, kurangnya dukungan manajerial, jam kerja yang panjang dan giliran kerja ganda, tuntutan fisik pekerjaan, pelecehan seksual, dan kerja shift. Sementara beberapa dari bahaya ini mungkin lebih baik diklasifikasikan sebagai faktor organisasi, banyak di antaranya (jam kerja yang panjang, giliran kerja ganda, kurangnya dukungan manajerial) cenderung demikian menciptakan stres dan masalah psikososial bagi pekerja dan termasuk di sini.

Risiko psikososial berjalan seiring dengan pengalaman stres terkait pekerjaan. Stres kerja diartikan sebagai suatu interaksi antara kondisi kerja dengan sifat-sifat pekerja yang mengubah fungsi fisik maupun fungsi psikis yang normal. Stres kerja merupakan tuntutan pekerjaan yang tidak merujuk pada kondisi dari pekerjaan yang mengancam individu, stres kerja timbul sebagai bentuk ketidakharmonisan individu dengan lingkungan kerja. Stres kerja merupakan bentuk respon tubuh terhadap tekanan-tekanan, tuntutan-tuntutan fisik atau lingkungan dan situasi yang mengganggu pelaksanaan tugas perawat 
Stres tidak selalu buruk dan merupakan bagian normal dari kehidupan sehari-hari. Namun, stres dapat menimbulkan perasaan tidak nyaman jika seseorang tidak mampu menanganinya. Stres terjadi apabila individu menilai situasi yang ada pada dirinya adalah situasi yang mengancam. Dalam hal lain stres kerja adalah suatu kondisi ketegangan yang mempengaruhi emosi, proses berpikir dan kondisi seseorang. Tingkat stress paling tinggi akan mempengaruhi kondisi fisik dan psikologis seseorang dan pada psikologis seseorang dan pada gilirannya akan mempengaruhi kinerja yang semakin menurun.

Stres yang terjadi pada setiap individu berbeda-beda tergantung pada masalah yang dihadapi dan kemampuan untuk menyelesaikan masalah tersebut. Jika seseorang mengalami stres terlalu besar, maka akan mengganggu kemampuan seseorang untuk menghadapi lingkungan dan pekerjaannya.

Perawat dengan latar belakang pendidikan tinggi umumnya memiliki pengetahuan dan keterampilan yang lebih baik dalam merawat dan menghadapi pasien serta keluarganya dan para dokter yang bertugas. Perawat berusia lebih dari 40 tahun lebih dapat mengendalikan stres. Perawat dengan usia yang lebih tua lebih matang kejiwaannya, bijaksana, berpikir rasional, mengendalikan emosi, toleran terhadap pandangan dan perilaku yang berbeda darinya, serta lebih matang tingkat intelektual dan psikologisnya.

Sumber stres dalam profesi keperawatan berhubungan dengan interaksi terhadap pasien dan profesi kesehatan lain. Perawat memiliki banyak tugas yang harus dilakukan dibandingkan profesi lain. Pengalaman stres adalah pengalaman pribadi dan bersifat subjektif. Perawat Indonesia mengalami stres kerja, dengan gejala sering pusing, kurang ramah, merasa lelah, kurang istirahat akibat beban kerja berat serta penghasilan tidak memadai.

Faktor yang mempengaruhi stress kerja perawat adalah jumlah tindakan yang harus diselesaikan tidak sebanding dengan jumlah tenaga perawat, jumlah rata-rata jam perawatan yang di butuhkan untuk memberikan pelayanan langsung pada pasien melebihi dari kemampuan seseorang, keinginan untuk berprestasi kerja, tuntutan pekerjaan tinggi serta dokumentasi asuhan keperawatan. Dapat juga disebabkan oleh banyaknya pertanyaan yang muncul dari pasien/keluarga pasien mengenai sakit yang dialami, ketegangan dalam berinteraksi dengan atasan dan sesama pekerja, pekerjaan yang menuntut konsentrasi yang tinggi, dan lain-lainnya. 
Stres kerja perawat pada tingkat sedang yaitu perawat menghindari masalah, berpikir terhadap hal-hal kecil, merasa kehilangan konsentrasi, merasa tidak cocok dengan pekerjaan dan merasa tidak cukup waktu untuk menyelesaikan pekerjaan.

Kelelahan kerja adalah keadaan dimana tubuh mengalami penurunan daya tahan kerja yang di akibatkan adanya beban kerja yang diterima seseorang pada saat bekerja. Perawat dapat melakukan kesalahan dalam pelayanan karena kelelahan yang dirasakan. Kondisi kerja merupakan salah satu kontribusi paling besar terhadap terjadinya stres kerja kemudian tipe kepribadian dan beban kerja.

Kelelahan kerja akan menurunkan kinerja, menurunkan kapasitas kerja dan ketahanan kerja yang ditandai oleh sensasi lelah, motivasi menurun, aktivitas menurun. Karakteristik kelelahan kerja akan meningkat dengan semakin lamanya pekerjaan yang dilakukan, sedangkan menurunnya rasa lelah dapat meningkatkan kesalahan kerja dan memberikan peluang terjadinya kecelakaan kerja dalam industri.

Kelelahan emosional, sebagian besar diduga berhubungan dengan stres pekerjaan. Melalui wawancara, dapat diketahui seorang perawat yang bekerja dengan berinisial A mengatakan bahwa dirinya sering mengalami kelelahan fisik maupun kelelahan pikiran, karena rutinitas yang padat dengan istirahat yang minim. Hasil dari kelelahan emosional yang dialami oleh seseorang, orang tersebut tidak responsif terhadap orang-orang yang mereka layani, dan juga merasa bahwa pekerjaannya sebagai penyiksaan karena berfikir bahwa dirinya sendiri tidak mampu menanggung hari-hari berikutnya dan selalu merasa tegang.

Terdapat beberapa hal yang pada akhirnya mempengaruhi timbulnya kelelahan emosi pada seseorang. Terdapat empat dimensi yang diyakini akan memudahkan dalam pengukuran kelelahan emosi, yaitu:

1. Beban kerja (workload), yaitu tekanan yang timbul dari pekerjaan yang dikerjakan seseorang.

2. Tekanan waktu (Time Pressure) yaitu timbul dari ketegangan yang dihadapi oleh seseorang dalam menyelesaikan pekerjaannya, dimana ketegangan itu dapat timbul dari sebuah tuntutan penyelesaian pekerjaan (deadline). 
3. Kurangnya dukungan sosial (Lack of Social Support) yaitu keadaan dimana terjadi kekurangan terhadap dukungan dari orangorang di sekitarnya untuk melakukan pekerjaan.

4. Stress karena peran (Role Stress), diartikan bahwa seseorang mengalami sebuah ambiguitas terhadap pekerjaannya dan tengah menghadapi konflik dalam pekerjannya.

Penerapan manajemen rumah sakit tentang lingkungan kerja perawat yang efektif akan mempertahankan rasa pengendalian diri dalam lingkungan kerja, sehingga beberapa hal yang bersifat negatif dianggap sebagai suatu tantangan. Selain itu mekanisme koping perawat yang bisa beradaptasi terhadap segala tekanan yang negatif akan mampu menghindarkan perawat dari stres kerja yang berdampak pada kualitas perilaku caring perawat.

Untuk mengatisipasi bahaya psikososial stress terhadap kelelahan kerja pada perawat di perlukan menyusun program kegiatan berupa pelatihan peningkatan motivasi bagi perawat dan memfasilitasi adanya diskusi dengan tim kesehatan lain dalam rangka menurunkan tingkat stres kerja perawat dan pengaturan mengenai pelaksanaan kerja perawat untuk lebih menekankan pelaksanaan caring dalam merawat pasien sehingga dapat memberikan pelayanan yang terbaik bagi pasien. Kemudian dibuat suatu sistem penghargaan dan kontrol terhadap pelayanan yang diberikan oleh perawat pada pasien. Dan jugaa tingkat stress pada perawat sebaiknya pihak rumah sakit memberikan fasilitas-fasilitas pemutar music dan pemberian ruangan khusus agar perawat dapat rileks.

\section{Penutup}

Kelelahan kerja dapat menimbulkan beberapa dampak diantaranya kelelahan emosi seperti perawat merasa kesel, perawat mengalami kelelahan eksternal seperti: marah kepada pasien, serta mengalami kelelahan internal adanya keinginan untuk pindah kerja.

Dengan menyadari bahwa dalam setiap pekerjaan, dalam kenyataannya memiliki tingkat kesulitan dan tantangan yang berbeda-beda. maka setiap perawat akan menyikapi dan memandang segala hal yang bersifat negatif tanpa menimbulkan suatu beban dan tekanan yang berat sehingga mereka terhindar dari stres. 
Sebagian perawat menganggap bahwa menjadi pribadi yang memiliki sikap yang positif dan tegar dalam menghadapi permasalahan menjadi hal penting untuk dapat eksis dalam organisasi, sehingga membuat mereka tetap tegar dalam menghadapi tugas-tugas yang berat, sehingga mereka memiliki tingkat kelelahan yang rendah.

Dapat mengatasi stres kerja dengan cara menerima apa yang menjadi tanggung jawab mereka dan saling menghargai sesama perawat dan dapat mengatasi kelelahan kerja dengan cara beristirahat dengan cukup dirumah setelah selesai jam bekerja.

\section{Daftar Pustaka}

Aini, F., \& Purwaningsih, P. (2013). Hubungan antara beban kerja dengan stres kerja perawat di Instalasi Gawat Darurat RSUD Kabupaten Semarang. Jurnal Manajemen Keperawatan, 1(1).

Daniah, R. Z. F. (2016). HUBUNGAN GEJALA STRES KERJA DENGAN BAHAYA PSIKOSOSIAL PADA PEKERJA PENGUMPUL TOL CABANG JAGORAWI DI PT. JASA MARGA (PERSERO) TBK TAHUN 2016. Jurnal Ilmu Kesehatan, 8, 2.

Desima, R. (2015). Tingkat stres kerja perawat dengan perilaku caring perawat. Jurnal keperawatan, 4(1).

Fathi, A., \& Simamora, R. H. (2019, March). Investigating nurses' coping strategies in their workplace as an indicator of quality of nurses' life in Indonesia: a preliminary study. In IOP conference series: Earth and Environmental science (Vol. 248, No. 1, p. 012031). IOP Publishing.

Harsono, H., Damayanti, M., \& Setiawati, E. P. (2017). Stres Kerja pada Perawat di Rumah Sakit dan Fasilitas Pelayanan Kesehatan Primer. eJournal Kedokteran Indonesia, 5(1), 12-17.

Indragiri, S., \& Yuttya, T. (2018). MANAJEMEN RISIKO K3 MENGGUNAKAN HAZARD IDENTIFICATION RISK ASSESSMENT AND RISK CONTROL (HIRARC). Jurnal Kesehatan, 9(1), 1080-1094. 
Ismail, F., \& Supriyadi, S. (2020). HUBUNGAN STRES KERJA DENGAN KELELAHAN KRONIS PADA PERAWAT DI RUANG RAWAT INAP RSUD WONOSARI. JURNAL KEPERAWATAN AKPER YKY YOGYAKARTA, 12(1), 9-18.

Kurniawati, E., Sugiono, S., \& Yuniarti, R. (2014). Analisis Potensi Kecelakaan Kerja Pada Departemen Produksi Springbed Dengan Metode Hazard Identification And Risk Assessment (HIRA)(Studi Kasus: PT. Malindo Intitama Raya, Malang, Jawa Timur). Jurnal Rekayasa Dan Manajemen Sistem Industri, 2(1), p11-23.

Lendombela, D. P., Posangi, J., \& Pondaag, L. (2017). Hubungan Stres Kerja Dengan Kelelahan Kerja Perawat Di Ruang Rawat Inap RSU Gmim Kalooran Amurang. JURNAL KEPERAWATAN, 5(1).

Noviyanti, I., \& Supriyadi, S. (2020). Hubungan Kondisi Kerja dengan Kelelahan Kronis pada Perawat di Ruang Rawat Inap RSUD Wonosari. JURNAL KEPERAWATAN AKPER YKY YOGYAKARTA, 12(2), 71-79.

Salikunna, N. A., \& Towidjojo, V. D. (2011). Penerapan Sistem Manajemen Kesehatan dan Keselamatan Kerja di Rumah Sakit Bersalin Pertiwi Makassar. Biocelebes, 5(1).

Simamora, R. H. (2020). Learning of Patient Identification in Patient Safety Programs Through Clinical Preceptor Models. Medico Legal Update, 20(3), 553-556.

SITUNGKIR, D., \& SKM, M. BAHAYA PSIKOSOSIAL DAN STRES KERJA.

Walton, A. L., \& Rogers, B. (2017). Workplace hazards faced by nursing assistants in the United States: a focused literature review. International journal of environmental research and public health, 14(5), 544.

Wijaya, C. P. (2019). Pengaruh Burnout Syndrome terhadap Proses Asuhan Keperawatan (Studi pada Perawat Rumah Sakit Medika Utama Blitar). REVITALISASI, 5(3), 23-36. 